\title{
HUBUNGAN PELAYANAN KB IUD TERHADAP TINGKAT KEPUASAN AKSEPTOR KB IUD
}

\section{THE CORELATION OF THE IUD FAMILY PLANNING SERVICE WITH THE LEVEL OF SATISFACATION AT IUD ACCEPTORS}

\author{
Nevia Zulfatunnisa, Qurrota Ainy \\ Prodi DIII Kebidanan STIKES PKU Muhammadiyah Surakarta \\ email: Nevia.zulfa@gmail.com
}

\begin{abstract}
Abstrak
Pelayanan keluarga berencana bertujuan untuk meningkatkan kesejahteraan ibu serta anak melalui pengendalian kelahiran dan pengendalian pertumbuhan penduduk. Hasil studi pendahuluan didapatkan data seluruh akseptor KB IUD tahun 2015 IUD 86 orang. Hasil yang didapatkan 15 akseptor merasa puas dan 5 akseptor tidak puas dengan pelayanan KB IUD meliputi : tanggapan bidan, privasi, sikap bidan, dan konseling yang diberikan. Tujuan penelitian ini Untuk mengetahui hubungan pelayanan KB IUD terhadap tingkat kepuasan akseptor KB IUD. Metode penelitian ini menggunakan deskriptif analitik dengan pendekatan cross sectional. Populasi penelitian masyarakat Sangkrah yang menggunakan KB IUD dengan tekhnik sample menggunakan Non Random Sampling dengan metode quota sampling sejumlah 30 responden. Instrumen penelitian menggunakan quesioner. Analisa yang digunakan berupa spearman rank test pada signifikan 5\%..Hasil penelitian didapatkan mayoritas pelayanan yang baik sebanyak 63,3\%, dan minoritas pelayanan yang kurang $20 \%$, sedangkan pada mayoritas tingkat kepuasan yang puas sebanyak 36,8 \% dan minoritas tingkat kepuasan yang sangat tidak puas sebanyak $20 \%$. Pada analisa bivariet ini menunjukkan nilai $\rho>\alpha(0.650>0.364)$.
\end{abstract}

Kata Kunci: Pelayanan, kepuasan, KB IUD.

\begin{abstract}
Family planning services aims to improve welfare mother and a son through birth control and controlling population growth. The result of astudy introduction obtained data all acceptors IUD 201586 people. The result of 15 acceptors were satisfied or 5 acceptors were satisfied with the services provided family planning at IUD includes : response midwives, privasy, midwive attitudes, and conseling given. This research used was deskriptif analytic with cross sectional method. The aim of this reseach is to know correlation of the IUD family planning service with the level of satisfaction of IUD acceptors. The population of this research is the people in Sangkrah of IUD acseptors with 30 repondents. Furthermore, this research used non random sampling type with quota sampling method, while it used survey for its instrument. The data analysis was done by spearman ran test on signifikan 5\%. The research results obtained the majority of good service as much as $63,3 \%$, and a minority of service less $20 \%$, while in the majority of level of satisfaction satisfied as much as 36.8\%, very dissatisfied as much as 20\%. On bivariet analysis shows $\rho>\alpha$ $(0650>0.364)$.
\end{abstract}

Keywords: Service, satisfacation, KB IUD. 


\section{PENDAHULUAN}

Pelayanan KB IUD adalah bagaimana akseptor dilayani oleh suatu sistem yang memberikan pelayanan KB IUD yang akan menjamin bahwa klien dilayani dengan tanggung jawab dan perhatian, mendapat informasi yang memadai tentang berbagai pilihan kontrasepsi yang tersedia untuk memenuhi kebutuhan serta diberi bantuan dalam pemasangan, pelepasan dan pemilihan jenis kontrasepsi yang akan berlanjut, tanpa efek samping yang berarti hingga tujuan klien untuk menjarangkan atau membatasi kelahiran tercapai (Saifuddin, 2005).

Pelayanan keluarga berencana bertujuan untuk meningkatkan kesejahteraan ibu dan anak serta mewujudkan keluarga kecil yang bahagia dan sejahtera melalui pengendalian kelahiran dan pengendalian pertumbuhan penduduk Indonesia serta terciptanya penduduk yang berkualitas, sumber daya manusia yang bermutu dan meningkatkan kesejahteraan keluarga. Akses terhadap pelayanan keluarga berencana yang bermutu merupakan suatu upaya mencapai pelayanan kesehatan reproduksi. Secara khusus dalam hal ini termasuk hak setiap orang untuk memperoleh informasi dan akses terhadap berbagai metode kontrasepsi yang aman, efektif dan terjangkau. (Saifudin, 2005).

Badan Koordinasi Keluarga Berencana Nasional (BKKBN) berupaya melakukan pemerataan akses dan peningkatan kualitas pemakaian kontrasepsi di Indonesia dengan fokus utama pada kecenderungan pola pemakaian kontrasepsi yang dinilai tidak rasional. Kecenderungan pemakaian jenis kontrasepsi di Indonesia tidak sesuai dengan pola di negara lain. Contohnya pemakaian Intra Uterine Device (IUD) atau Alat Kontrasepsi Dalam Rahim (AKDR) semakin menurun dari tahun ke tahun (BKKBN, 2014).

Berdasarkan data SDKI 2012, kecenderungan pola pemakaian kontrasepsi terbesar adalah suntik $(31,6 \%)$, pil $(13,2 \%)$, IUD/AKDR $(4,8 \%)$, implan $(2,8 \%)$, Metode Operasi Wanita / MOW (3,1\%), senggama terputus $(2,2 \%)$, pantang berkala $(1,5 \%)$, kondom $(1,3 \%)$, Metode Operasi Pria / MOP $(0,2 \%)$, dan metode lainnya $0,4 \%$. Pemakaian metode kontrasepsi suntik memperlihatkan kecenderungan peningkatan pada beberapa kurun waktu terakhir ini, yaitu tahun 1991 hanya $11,7 \%$, tahun 1994 sebesar $15,2 \%$, tahun 1997 sebesar 21,1\%, tahun 2003 sebesar 27,8\% dan tahun 2007 sebesar 31,6\% dan tahun 2012 sebesar 33,2\%. Sebaliknya, pema- kaian metode IUD/AKDR menurun dari waktu ke waktu, yaitu tahun 1991 sebesar 13,3\%, tahun 1994 sebesar 10,3\%, tahun 1997 sebesar 9,9\%, tahun 2003 sebesar 8,1\%, tahun 2007 hanya sebesar 6,2\% dan tahun 2012 hanya sebesar 4,8\% (BKKBN, 2012).

Di Jawa Tengah 2013, jenis alat kontrasepsi yang digunakan peserta $\mathrm{KB}$ aktif adalah suntik $(54,84 \%)$, pil $(17,43 \%)$, implan $(9,55 \%)$, IUD/AKDR $(9,48 \%)$, MOP/MOW (7,28\%), dan kondom $(1,42 \%)$. Dari data tersebut dapat diketahui bahwa mayoritas penduduk Jawa Tengah menggunakan alat kontrasepsi suntik, yaitu sebesar $54,48 \%$. Hanya ada $9,48 \%$ saja yang menggunakan IUD/AKDR (Dinkes Jateng, 2013).

Berdasarkan Profil Kesehatan Surakarta tahun 2013 terdapat 57.034 peserta KB aktif, dengan persentase sebagai berikut 27.189 $(47,67 \%)$ peserta Suntik, $12.028(21,1 \%)$ peserta IUD, 7.899 (13, 85\%) peserta Pil, 4.941 (8,66\%) peserta Kondom, $2.406(4,22 \%)$ peserta Implan, $2.391(4,2 \%)$ peserta MOW dan $180(0,3 \%)$ peserta MOP (Profil Kesehatan Surakarta, 2013). Pada tahun 2014, jenis alat kontrasepsi yang digunakan adalah suntik $(55.05 \%)$, pil $(14,84 \%)$, MOW/MOP (9,5\%), IUD (8,04\%), implan $(6,66 \%)$, dan kondom $(5,91 \%)$.

Berdasarkan data tersebut, peserta IUD menempati urutan keempat. Ironisnya, jumlah peserta KB aktif IUD/AKDR menurun dari tahun ke tahun Pemakaian metode IUD/AKDR di Indonesia nyata-nyata mampu menurunkan angka TFR secara signifikan. Akan tetapi, pemakaian metode kontrasepsi AKDR cenderung menurun dari waktu ke waktu. Salah satu faktor yang mempengaruhi peningkatan atau penurunan penggunaan metode IUD/AKDR adalah Komunikasi, Informasi dan Edukasi (KIE) yang intensif dan efektif baik pada kelompok masyarakat maupun perorangan (Dinkes Jateng, 2014).

Proses KIE dan informed choice belum dilaksanakan secara benar dan belum luas cakupannya. Akibatnya, pemilihan kontrasepsi secara rasional masih belum tersosialisasi dengan baik. Padahal, perkembangan teknologi kontrasepsi sesungguhnya didasari tujuan penggunaannya. Selain itu, perlu diingat bahwa kontrasepsi rasional bukan hanya mempertimbangkan aspek efektifitas teknologi kontrasepsi dan tujuan penggunaan kontrasepsi (postponing, spacing atau limiting), tetapi harus mempertimbangkan secara rasional dari kriteria penerimaan dari 
aspek medis (medical eligible criteria) dan mutu pelayanan.

Pengertian mutu pelayanan mencakup dua dimensi, yaitu klien dan petugas pelayanan. Dari dimensi klien, pelayanan dianggap bermutu apabila pelayanan mampu memberikan kepuasan kepada klien (client satisfaction). Dengan kata lain, pelayanan yang bermutu adalah pelayanan yang mampu memenuhi kebutuhan dan tuntutan serta hak-hak klien. Dari dimensi penyedia layanan, pelayanan yang bermutu adalah pelayanan yang sesuai dengan kode etik dan memenuhi standar profesi pelayanan yang telah ditetapkan (BKKBN, 2014).

Dengan demikian, kepuasan klien ini sangat penting. Dimensi mutu layanan yang berhubungan dengan kepuasan klien dapat mempengaruhi kesehatan masyarakat dan kesejahteraan masyarakat. Klien yang merasa puas terhadap layanan akan mematuhi pengobatan dan mau datang berobat kembali (Imbalo S. 2006).

\section{METODE PENELITIAN}

Penelitian ini dirancang menggunakan rancangan penelitian deskriptif analitik. Tempat penelitian ini dilaksanakan di Puskesmas Sangkrah Surakarta. Populasi dalam penelitian ini adalah akseptor KB IUD yang melakukan kunjungan di Puskesmas Sangkrah Surakarta sejumlah 86 orang. Dengan teknik Non random sampling sejumlah 30 responden. Instrumen yang digunakan dalam penelitian ini adalah kuesioner. Uji validitas dalam penelitian ini menggunakan pearson product moment dengan nilai $\mathrm{r}$ hitung tertinggi untuk pelayanan KB IUD 0,909 dan untuk $\mathrm{r}$ hitung tertinggi untuk tingkat kepuasan akseptor KB IUD 0,864 dan uji reliabilitas menggunakan $\alpha$-Cronbach didapatkan nilai $\alpha=$ 0,941 pada kuesioner pelayanan dan untuk kuesioner tingkat kepuasan diperoleh $\alpha=0,946$. Analisa data menggunakan uji spearman rank.

\section{HASIL PENELITIAN DAN \\ PEMBAHASAN \\ Hasil Penelitian}

1. Analisis Univariat

a. Karakteristik Responden Penelitian
Tabel 1. Distribusi frekuensi responden yang Menerima Pelayanan KB IUD berdasarkan umur di Puskesmas Sangkrah.

\begin{tabular}{lccc}
\hline No & Umur & Frekuesi & $\%$ \\
\hline 1. & $22-30$ th & 3 orang & $10 \%$ \\
2. & $31-40$ th & 10 orang & $33.3 \%$ \\
3. & $>40$ th & 17 orang & $56.7 \%$ \\
& Total & 30 orang & $100 \%$ \\
\hline
\end{tabular}

Berdasarkan table 1 menunjukkan bahwa mayoritas responden memiliki usia $>40$ tahun sebanyak $56.7 \%$.

b. Variabel Dependen

Tabel 2. Distribusi Frekuensi Responden Berdasarkan Pelayanan yang Diberikan di Puskesmas Sangkrah

\begin{tabular}{cllc}
\hline No & $\begin{array}{c}\text { Pelayan } \\
\text { an }\end{array}$ & \multicolumn{1}{c}{ Frek } & $\%$ \\
\hline 1 & Baik & 19 orang & $63,3 \%$ \\
2 & Cukup & 5 orang & $16,7 \%$ \\
3 & Kurang & 6 orang & $20 \%$ \\
& Total & 30 orang & $100 \%$ \\
\hline
\end{tabular}

Berdasarkan tabel 2 diperoleh bahwa mayoritas pelayanan responden memiliki pelayanan KB IUD yang baik yaitu $63,3 \%$ responden dan minoritas responden memiliki pelayanan yang kurang yaitu $20 \%$ responden.

c. Variabel Independen

Tabel 3. Distribusi Frekuensi Responden Berdasarkan Tingkat Kepuasan Akseptor KB IUD di Puskesmas Sangkrah

\begin{tabular}{llcc}
\hline \multirow{2}{*}{ No } & $\begin{array}{c}\text { Tingkat } \\
\text { Kepuasan }\end{array}$ & Frek & $\%$ \\
\hline 1 & Sangat Puas & 7 orang & $23,3 \%$ \\
& Puas & & \\
2 & Tidak Puas & 11 orang & $36,7 \%$ \\
3 & Sangat Tidak & 5 orang & $16,7 \%$ \\
4 & Puas & 7 orang & $23,3 \%$ \\
& Total & 30 orang & $100 \%$ \\
\hline
\end{tabular}


Berdasarkan tabel 3 diperoleh bahwa mayoritas responden memiliki tingkat kepuasan yang puas terhadap pelayanan KB IUD sebanyak 11 orang (36,7\%) dan minoritas responden yang memiliki tingkat kepuasan tidak puas sebanyak 5 orang $(16,7 \%)$.

\section{Analisis Bivariat}

Tabel 4. Cross Tabulation Hubungan

Pelayanan KB IUD terhadap Tingkat Kepuasan Akseptor KB IUD di Puskesmas Sangkrah Surakarta

\begin{tabular}{lllll}
\hline $\begin{array}{l}\text { Pelayanan/ } \\
\text { Kepuasan }\end{array}$ & STP & TP & P & SP \\
\hline Kurang & $50 \%$ & $33,3 \%$ & $16,7 \%$ & $0 \%$ \\
Cukup & $60 \%$ & $16,7 \%$ & $16,7 \%$ & $0 \%$ \\
Baik & $16,7 \%$ & $10,5 \%$ & $47,4 \%$ & $36,8 \%$ \\
Total & $36,8 \%$ & $16,7 \%$ & $36.7 \%$ & $36,8 \%$ \\
\hline
\end{tabular}

\section{Pembahasan}

\section{Pelayanan KB IUD}

Data hasil penelitian berdasarkan pelayanan yang didapatkan oleh responden menunjukkan bahwa mayoritas memiliki pelayanan KB IUD yang baik yaitu 63,3\% responden, sedangkan yang mendapatkan pelayanan yang cukup 16,7 \% reponden dan minoritas responden memiliki pelayanan yang kurang yaitu $20 \%$ responden.

Pelayanan yang diberikan kepada akseptor KB IUD meliputi kehandalan, daya tanggap, jaminan, empati dan bukti langsung. Dimana dalam penelitian ini kehandalan dinilai dari cara bidan memberikan pelayanan terhadap akseptor KB IUD hasil yang didapatkan sebagian akseptor mengatakan bidan mampu memberikan pelayanan yang baik kepada akseptor seperti akseptor langsung dilayani di ruang pemeriksaan $\mathrm{KB}$ dengan tanggap dan bidan memberikan pilihan $\mathrm{KB}$ apa yang akan dipakai sehingga bidan memberikan inform choice kepada akseptor tentang KB apa yang tepat untuk akseptor. Sehingga akseptor merasa senang atas pelayanan yang didapatkan, ada beberapa akseptor yang mengatakan bidan kurang memberikan pelayanan dalam komunikasi terhadap akseptor, sehingga akseptor bingung memilih $\mathrm{KB}$ apa yang tepat untuk dirinya.

Pada aspek daya tanggap, akseptor merasa mendapatkan pelayanan yang baik karena bidan dapat memberikan pelayanan yang diharapkan seperti tanggap dalam keluhan yang dialami oleh akseptor, bidan memberi saran dan nasehat untuk penggunana KB IUD ini, bidan juga menjelaskan bagaimana proses pelayanan KB IUD yang akan diberikan pada akseptor.

Selanjutnya aspek jaminan dengan kondisi yang menyatakan bahwa kerahasiaan dan privasi sangat dijaga oleh bidan,bidan menjaga privasi salah satunya menutup pintu saat dilakukan pemasangan KB IUD, dan memberikan surat persetujuan (inform consent) pada akseptor ketika akseptor setuju atas pilihannya. Akseptor juga mendapat pelayanan yang baik pada aspek jaminan ini karena sesuai dengan kebutuhan, akseptor percaya dengan pelayanan yang diberikan, dan akseptor merasa nyaman dan aman mendapatkan pelayanan di puskesmas sangkrah.

Demikian juga pada aspek empaty, seperti bidan mendengarkan keluhan pasien dan merasakan apa yang dirasakan oleh pasien, bidan juga memberi tanggapan terhadap pasien, akseptor merasa senang dengan pelayanan bidan yang ramah dan sopan saat berkomunikasi dan memberikan tanggapan yang baik saat akseptor menceritakan keluhannya, bidan juga menjelaskan indikasi, kontraindikasi, keuntungan, kerugian dan efek samping dari penggunaan KB IUD ini. Saat memberikan penjelasan bidan menggunakan kata kata yang mudah dimengerti oleh akseptor serta bidan juga memberikan penjelasan dengan menggunakan lembar balik sehingga akseptor ada gambaran bagaimana KB IUD itu.

Berdasarkan aspek bukti langsung, hasil penelitian menunjukkan bahwa akseptor mendapat pelayanan yang baik dengan kondisi yang menyatakan bahwa ruangan nyaman, semua alat bersih, bidan mencuci tangan dan memakai sarung tangan sebelum melakukan tindakan, obat atau alat kontrasepsi masih dalam keadaan bersegel, tetapi beberapa akseptor mengatakan tidak mengerti apakah obat masih bersegel atau tidak karena bidan tidak memberitahu kepada akseptor KB tersebut. Hal ini sesuai pendapat Hartanto \& Hanafi (2005) yang menyatakan bahwa sarana dan fasilitas fisik yang dapat langsung dirasakan oleh pelanggan dalam pelayanan seperti kecukupan tempat duduk di ruang tunggu, kenyamanan ruang tunggu dan penampilan fisik petugas yang melayani termasuk menjamin mutu pelayanan.

Selama penelitian, peneliti juga melihat bahwa bidan dipuskesmas sangkrah memberikan pelayanan yang baik. Peneliti juga melihat 
langsung bahwa sebagian bidan terampil dalam memberikan pelayanan yang diberikan kepada akseptor, bidan menjawab semua pertanyaan yang dikeluhkan oleh akseptor, bidan juga menjelaskan bagaimana prosedur pemasangan KB IUD, menjelakan indikasi kontra indikasi, keuntungan, kerugian dan efek samping pada penggunaa KB IUD di sertai dengan lembar balik, bidan juga ramah dalam berkomunikasi sehingga menimbulkan rasa aman dan nyaman pada akseptor, peneliti juga melihat ruangan yang dipakai sangat nyaman, obat dan alat yang di gunakan dalam keadaan bersih dan masih bersegel, dalam melakukan tindakan bidan selalu mencuci tangan dan selalu menggunakan sarung tangan. Tetapi ada juga beberapa bidan yang kurang dalam pemberian pelayanan salah satunya yaitu kurang memberikan konseling sebelum pemberian KB IUD.

Sesuai menurut Zeithaml dalam Bustami (2011) pelayanan ini dikatakan baik karena pelayanan yang diberikan bidan sesuai dengan lima dimensi kualitas pelayanan yang meliputi kehandalan, daya tanggap, jaminan, empati dan bukti langsung.

Dalam penelitian ini juga sesuai menurut Bustami (2011) yaitu mutu pelayanan bagi pasien, penilaian jasa pelayanan kesehatan lebih terkait pada ketanggapan petugas memenuhi kebutuhan pasien, kelancaran komunikasi petugas dengan pasien, empati dan keramah tamahan petugas dalam melayani pasien dalam kesembuhan penyakit yang diderita oleh pasien.

Menurut asumsi peneliti pelayanan yang diberikan sesuai dengan teori yang ada, pelayanan yang ada sudah mencangkup lima dimensi pelayanan.

\section{Tingkat Kepuasan KB IUD}

Dalam penelitian ini di dapatkan responden yang merasa puas dan sangat puas terhadap pelayanan yang baik sebanyak 53,3\% sedangkan responden yang merasa sangat tidak puas terhadap pelayanan yang kurang sebanyak $20 \%$.

Pelayanan yang baik dapat memberikan kepuasan yang baik pada akseptor KB IUD. Dalam penelitian ini rata-rata responden mengatakan puas terhadap pelayanan yang diberikan seperti bidan ramah dalam melakukan komunikasi, penjelasan bidan mudah dimengerti sehingga akseptor merasa nyaman dengan pelayanan tersebut, tetapi sebagian merasa kurang puas pada aspek konseling yang diberikan bidan, seperti harus lebih ramah dan sopan saat berkomunikasi serta mendengarkan keluhan dengan baik, penjelasan yang disampaikan seharusnya sesuai dengan kebutuhan dan mudah dimengerti, bidan harus menjelaskan berbagai metode kontrasepsi yang ingin dipakai dan mengganti metode kontrasepsi, serta menjelaskan efek samping dan cara pemakaian.

Hal ini sesuai pendapat Husain (2007) Kepuasan pelanggan ditentukan oleh persepsi pelanggan atas performance produk atau jasa dalam memenuhi harapan pelanggan. Pelanggan merasa puas apabila harapannya terpenuhi atau akan sangat puas jika harapan pelanggan terlampaui.

Didukung dengan penelitian sebelumnya Herlianti Pasaribu dengan judul "Kepuasan Akseptor KB terhadap Pelayanan KB di Klinik Bersalin N.Tambunan" di Medan Tahun 2009 telah melakukan penelitian sebanyak 73 akseptor $\mathrm{KB}$ dengan hasil penelitian menunjukkan bahwa dari 73 orang responden terdapat $47 \%$ akseptor yang memiliki tingkat kepuasan tinggi, 52\% akseptor yang memiliki tingkat kepuasan sedang dan $1 \%$ akseptor yang memiliki tingkat kepuasan rendah terhadap pelayanan $\mathrm{KB}$ di klinik bersalin N. Tambunan Medan.

Penelitian ini dikatakan puas jika akseptor mendapatkan apa yang ia butuhkan, jika yang dibutuhkan terpebuhi maka akan menimbulkan rasa kepuasan dan sebaliknya jika akseptor tidak mendapatkan apa yang dibutuhkan maka akseptor tidak akan merasa puas terhadap apa yang yang diberikan.

Dalam penelitian ini sesuai menurut Husain (2007), kepuasan pelanggan ditentukan oleh persepsi pelanggan atas performance produk atau jasa dalam memenuhi harapan pelanggan. Pelanggan merasa puas apabila harapannya terpenuhi atau akan sangat puas jika harapan pelanggan terlampaui.

Menurut penulis ada kesesuaian antara hasil dan teori yang ada.

\section{Hubungan Antara Pelayanan KB IUD Ter- hadap Tingkat Kepuasan akseptor KB IUD}

Hasil uji statistika dengan menggunakan Spearman Rank menunjukkan bahwa ada hubungan yang signifikan antara pelayanan KB IUD terhadap tingkat kepuasan akseptor KB IUD dengan hasil $\rho>\alpha(0,650>0,362)$ pada tingkat signifikan 5\%. Hal ini membuktikan pelayanan KB IUD berpengaruh signifikan terhadap tingkat 
kepuasan akseptor KB IUD yang berarti semakin baik pelayanan yang diterima responden maka tingkat kepuasan akseptor KB IUD semakin puas.

Menurut Imbalo (2006) bahwa hubungan antara pelayanan KB IUD terhadap tingkat kepuasan akseptor KB IUD dapat dilihat pada tabel 8. Hal ini menunjukkan semakin baik pelayanan yang diberikan pada responden maka semakin tinggi juga tingkat kepuasan responden dan semakin kurang pelayanan yang diberikan pada responden maka tingkat kepuasan responden semakin tidak puas. Adanya hubungan ini juga berguna untuk meningkatkan pelayanan kesehatan untuk dapat memahami dan melaksanakan pelayanan yang sesuai standar guna meningkatkan kepuasan pasien.

Dalam penelitian yang peneliti lakukan dengan pelayanan yang salah satu dipengaruhi oleh tingkat kepuasan, baiknya pelayanan yang diberikan kepada akseptor akan mempengaruhi tingkat kepuasannya.

Hasil penelitian ini sesuai dengan teori Husain (2007), bahwa kepuasan pelanggan ditentukan oleh persepsi pelanggan atas performance produk atau jasa dalam memenuhi harapan pelanggan. Pelanggan merasa puas apabila harapannya terpenuhi atau akan sangat puas jika harapan pelanggan terlampaui.

Menurut pendapat Kotler ( 2007 ) hasil penelitian ini sesuai dengan teori bahwa pelayanan yang bermutu dapat menghasilkan suatu kepuasan bagi klien, sehingga dapat dirumuskan bila unsur-unsur dimensi kualitas pelayanan yang diterima sesuai dengan unsurunsur dimensi kualitas pelayanan yang diharapkan maka kualitas pelayanan dinilai baik dan memuaskan.

Didukung dengan penelitian sebelumnya Nia Wahyuningrum dengan judul "Gambaran Tingkat Kepuasan Pasien Terhadap Kualitas Pelayanan KB AKDR (Alat Kontrasepsi Dalam Rahim)" di Di Puskesmas Wonosobo I Kecamatan Wonosobo Kabupaten Wonosobo, telah melakukan penelitian sebanyak 85 responden dengan hasil analisis menunjukkan bahwa pasien merasa sangat puas terhadap kualitas pelayanan KB AKDR di Puskesmas Wonosobo I dengan prosentase sebesar $77,70 \%$.

Menurut penulis ada kesesuaian antara hasil dan teori yang ada.

\section{SIMPULAN}

Setelah dilakukan analisa data dan pembahasan hasil penelitian maka simpulan yang dapat diambil adalah sebagai berikut:

1. Pelayanan KB IUD terhadap tingkat kepuasan pada akseptor KB IUD puskesmas Sangkrah Surakarta memiliki pelayanan yang baik yaitu $63,3 \%$

2. Tingkat kepuasan akseptor KB IUD di Puskesmas Sangkrah Surakarta memiliki tingkat kepuasan yang puas sebanyak $36,8 \%$.

3. Ada hubungan yang signifikan antara pelayanan KB IUD terhadap tingkat kepuasan pada akseptor KB IUD puskesmas Sangkrah Surakarta dengan hasil hitung $\rho>\alpha(0,650>$ $0,364)$.

\section{REFERENSI}

BKKBN. 2014. Buku Panduan Praktis Pelayanan Keluarga Berencana.Jakarta.

Bustami. 2011. Penjaminan Mutu Pelayanan Kesehatan dan Akseptibilitasnya. Jakarta: Erlangga.

Dinas Kesehatan Pemerintah Provinsi Jawa tengah.2013.Profil kesehatan provinsi jawa tengah 2013.semarang: Dinas Kesehatan Pemerintah Provinsi Jawa tengah.

Hartanto \& hanafi. 2005. Keluarga Berencana dan Kontrasepsi. Jakarta: Pustaka Sinar Harapan.

Husain, U. 2005. Manajemen Riset dan Perilaku Konsumen. Jakarta : PT Gramedia Pusat.

Imbalo S. 2006. Jaminan Mutu Layanan Kesehatan: Dasar-Dasar Pengertian Dan Penerapan. Jakarta : EGC.

Kotler, P. \& Kevin.L.K.2007. Manajemen Pemasaran, Edisi Kedua Belas, Jilid 2, dialihbahasakan oleh Benjamin Molan. Jakarta: PT Indeks.

2009. Manajemen Pemasaran. Jakarta : Erlangga.

Saifudin \& Abdul B. 2005. Buku Panduan praktis Pelayanan kesehatan maternal \& neonatal. Jakarta : Yayasan Bina Pustaka Sarwaono Prawirohardjo. 